\title{
Effects of Tocilizumab in COVID-19 patients: a cohort study
}

Christine A. Vu ${ }^{1,2^{*}}$ (D) Kailynn J. DeRonde ${ }^{1}$, Ana D. Vega', Meshell Maxam', Gregory Holt ${ }^{3}$, Yoichiro Natori ${ }^{4}$, Jose Gonzales Zamora ${ }^{4}$, Veronica Salazar ${ }^{1}$, Renata Boatwright ${ }^{1}$, Stephen R. Morris ${ }^{4}$, Daniela de Lima Corvino ${ }^{4}$, Anmary Fernandez Betances ${ }^{4}$, Leah Colucci ${ }^{5}$, James Keegann ${ }^{5}$, Andy Lopez ${ }^{5}$, Andrew Hany Rezk ${ }^{5}$, Yvette Rodriguez ${ }^{5}$, Gabriela M. Moraru ${ }^{6}$, Susanne Doblecki ${ }^{4}$, David J. De La Zerda ${ }^{3}$ and Lilian M. Abbo ${ }^{4}$

\begin{abstract}
Background: Due to the lack of proven therapies, we evaluated the effects of early administration of tocilizumab for COVID-19. By inhibition of the IL-6 receptor, tocilizumab may help to mitigate the hyperinflammatory response associated with progressive respiratory failure from SARS-CoV-2.

Methods: A retrospective, observational study was conducted on hospitalized adults who received intravenous tocilizumab for COVID-19 between March 23, 2020 and April 10, 2020.

Results: Most patients were male (66.7\%), Hispanic (63.3\%) or Black (23.3\%), with a median age of 54 years. Tocilizumab was administered at a median of 8 days (range 1-21) after initial symptoms and 2 days (range 0-12) after hospital admission. Within 30 days from receiving tocilizumab, 36 patients (60.0\%) demonstrated clinical improvement, 9 (15.0\%) died, 33 (55.0\%) were discharged alive, and 18 (30.0\%) remained hospitalized. Successful extubation occurred in 13 out of 29 patients (44.8\%). Infectious complications occurred in 16 patients (26.7\%) at a median of 10.5 days. After tocilizumab was administered, there was a slight increase in $\mathrm{PaO}_{2} / \mathrm{FiO}_{2}$ and an initial reduction in CRP, but this effect was not sustained beyond day 10 .
\end{abstract}

Conclusions: Majority of patients demonstrated clinical improvement and were successfully discharged alive from the hospital after receiving tocilizumab. We observed a rebound effect with CRP, which may suggest the need for higher or subsequent doses to adequately manage cytokine storm. Based on our findings, we believe that tocilizumab may have a role in the early treatment of COVID-19, however larger randomized controlled studies are needed to confirm this.

Keywords: Coronavirus, COVID-19, Tocilizumab, Cytokine release syndrome

\footnotetext{
* Correspondence: christine.vu@jhsmiami.org

'Department of Pharmacy, Jackson Health System, Miami, FL, USA

2Jackson Memorial Hospital, Pharmacy Services, B069, 1611 NW 12th Ave,

Miami, FL 33136, USA

Full list of author information is available at the end of the article
}

(c) The Author(s). 2020 Open Access This article is licensed under a Creative Commons Attribution 4.0 International License, which permits use, sharing, adaptation, distribution and reproduction in any medium or format, as long as you give appropriate credit to the original author(s) and the source, provide a link to the Creative Commons licence, and indicate if changes were made. The images or other third party material in this article are included in the article's Creative Commons licence, unless indicated otherwise in a credit line to the material. If material is not included in the article's Creative Commons licence and your intended use is not permitted by statutory regulation or exceeds the permitted use, you will need to obtain permission directly from the copyright holder. To view a copy of this licence, visit http://creativecommons.org/licenses/by/4.0/. The Creative Commons Public Domain Dedication waiver (http://creativecommons.org/publicdomain/zero/1.0/) applies to the data made available in this article, unless otherwise stated in a credit line to the data. 


\section{Background}

Coronavirus Disease 2019 (COVID-19) is a rapidly progressing disease with severe lung injury as the primary cause of death [1]. Lung autopsies have revealed histologic patterns of diffuse alveolar damage and perivascular T-cell infiltration in the presence of intracellular severe acute respiratory syndrome coronavirus 2 (SARS$\mathrm{CoV}-2$ ) [2]. Once invaded, the virus is known to cause immune dysfunction by activating various proinflammatory cytokines, resembling that of cytokine release syndrome (CRS) [3, 4]. Among the numerous cytokines that are released, interleukin-6 (IL-6) is thought to play a major role in causing acute respiratory distress syndrome (ARDS) [5, 6].

Tocilizumab, an antagonist of soluble IL-6 receptor, is being evaluated for the management of COVID-19. Previously approved for the treatment of severe or lifethreatening chimeric antigen receptor (CAR) $\mathrm{T}$ cellinduced CRS, its ability to downregulate the immune system may reduce the detrimental effects of COVID19 [7, 8]. Studies have demonstrated tocilizumab to be associated with improvements in inflammatory markers, clinical response, and survival [9-21]. During an unprecedented time when proven effective therapies are lacking, we aimed to describe our real-life experience using tocilizumab for COVID-19.

\section{Methods}

\section{Setting}

We retrospectively analyzed hospitalized patients who received intravenous (IV) tocilizumab for COVID-19 within our large health care system in Miami, Florida between March 23, 2020 and April 10, 2020. Our health system is comprised of three acute care facilities with over 2500 licensed beds, including 150 adult intensive care unit beds. This study was approved by the University of Miami Institutional Review Board and Jackson Health System Clinical Research Review Committee and a waiver of informed consent was granted.

\section{Tocilizumab process}

Tocilizumab was restricted to the Antimicrobial Stewardship Program with pre-approval authorization for the management of highly suspected or laboratory-confirmed SARS CoV-2 infection. The approval consisted of a screening process to see if the patient first met criteria for tocilizumab, followed by a multidisciplinary discussion between the treating physician, infectious diseases physicians, pulmonary/critical care physicians, and pharmacists. Since February 2020, we followed an institutionspecific clinical protocol to determine when to consider COVID-19 investigational agents. For tocilizumab, patients were eligible if they met all of the following criteria: requiring $\geq 4$ liters of nasal cannula to maintain a $\mathrm{SpO} 2>$
93\%, demonstrate signs of clinical deterioration, have elevations in at least two inflammatory markers (interleukin- $6>40 \mathrm{pg} / \mathrm{ml}$, C-reactive protein $>10 \mathrm{mg} / \mathrm{dL}$, lactate dehydrogenase $>350 \mathrm{U} / \mathrm{L}$, ferritin $>1000 \mathrm{ng} / \mathrm{mL}$, Ddimer $>1 \mathrm{mcg} / \mathrm{ml}$ ). Tocilizumab was not recommended in patients with concominant bacterial infections, baseline ALT or AST $>5$ times the upper limit of normal (ULN), baseline platelet count $<100 \times 10^{9} / \mathrm{L}$, baseline absolute neutrophil count $<1.5 \times 10^{9} / \mathrm{L}$, or known history of diverticular disease or gastrointestinal perforation. However, exceptions were made if the treating physician believed the potential benefit could outweigh the risk. We administered flat doses of $400 \mathrm{mg}(30-100 \mathrm{~kg})$ and $600 \mathrm{mg}(>100 \mathrm{~kg}$ ) based on the limited evidence and resource allocations during that time $[11,22]$.

\section{Study participants}

Eligible patients were hospitalized adults (age $\geq 18$ years) with suspected or laboratory-confirmed SAR-CoV-2 infection and received at least one dose of IV tocilizumab. Any patients with high clinical suspicion for COVID-19 and later confirmed as negative by qualitative real-time PCR were excluded. All patients received standard of care treatment for COVID-19 based on our institutionspecific protocol, which at the time included hydroxychloroquine. Other therapies such as methylprednisolone, intravenous immunoglobulin, and convalescent plasma were recommended on a case-by-case basis. Data to support dexamethasone for COVID-19 was published after the completion of our study.

\section{Outcomes and definitions}

The electronic medical record was retrospectively reviewed to collect data on day $-1,0,1,2,3,4,5,7,10$, 14 and 30 relative to tocilizumab administration. We recorded laboratory and respiratory parameters, clinical improvement (defined as $\geq 2$-point reduction on the $\mathrm{WHO}$ COVID-19 ordinal scale), all-cause mortality, proportion of patients discharged, proportion of patients requiring oxygen support, proportion of patients requiring intensive care unit (ICU) care, proportion of patients successfully extubated (defined as not requiring re-intubation within the same hospitalization), and infectious complications within 30 days of receiving tocilizumab [23]. Infectious complications were defined as having a positive culture from a sterile site and treated by the medical team; we excluded cases of suspected colonization or contamination. Oxygenation was assessed by calculating $\mathrm{PaO}_{2} / \mathrm{FiO}_{2}$ from the morning arterial blood gas (ABG) and corresponding $\mathrm{FiO}_{2}$. For infrequent cases when an ABG was not available to measure the $\mathrm{PaO}_{2}$, we used an estimation formula based on the corresponding $\mathrm{SpO} 2, \mathrm{~S} / \mathrm{F}=64+0.84 * \mathrm{PaO}_{2} /$ $\mathrm{FiO}_{2}$ [24]. Acute respiratory distress syndrome (ARDS) was defined according to the Berlin Criteria [25]. 


\section{Statistical analysis}

Descriptive statistics were used to analyze our study population. Continuous variables were expressed as median and range while categorical variables were expressed as counts and percentages. Pearson's chi-squared test or Fisher's exact test (as appropriate) was used to compare categorical data. Mann-Whitney-Wilcoxon test was used to compare ordinal data. A $p$-value of $<0.05$ was considered statistically significant. All statistics were performed using SPSS (version 24, Chicago, IL).

\section{Results}

A total of 63 patients received tocilizumab during our study period (see Additional file 1: Appendix 1 supplemental material). Three patients were excluded after they were empirically treated as "patients under investigation" per the US Centers for Disease Control and Prevention criteria and then later confirmed to have a negative qualitative real-time PCR with an alternative diagnosis of infection. Patient characteristics are described in Table 1. Most patients were male (66.7\%), Hispanic (63.3\%) or Black (23.3\%), with a median age of 54 years old (range 26-87). The most common comorbidities were obesity (58.3\%), hypertension (53.3\%), and diabetes (25.0\%). The median time from symptom onset to hospital admission was 6 days. The median time from hospital admission to receiving tocilizumab was 2 days. The median time from symptom onset to receiving tocilizumab was 8 days, and this did not differ between the subgroup of patients who died. A majority of patients

Table 1 Patient characteristics

\begin{tabular}{|c|c|c|}
\hline & All $(N=60)$ & Died $(n=9)$ \\
\hline Age, median (range), years & $54(26-87)$ & $58(33-84)$ \\
\hline Male, $n(\%)$ & $40(66.7)$ & $8(88.9)$ \\
\hline \multicolumn{3}{|l|}{ Ethnicity } \\
\hline Hispanic & $38(63.3)$ & $6(66.7)$ \\
\hline Black & $14(23.3)$ & $2(22.2)$ \\
\hline White & $7(11.7)$ & $1(11.1)$ \\
\hline Asian & $1(1.7)$ & $0(0.0)$ \\
\hline \multicolumn{3}{|l|}{ Comorbidities } \\
\hline Obese (BMI > 30) & $35(58.3)$ & $6(66.7)$ \\
\hline Hypertension & $32(53.3)$ & $8(88.9)$ \\
\hline Diabetes & $15(25.0)$ & $3(33.3)$ \\
\hline Congestive heart failure & $4(6.7)$ & $1(11.1)$ \\
\hline Coronary artery disease & $1(1.7)$ & $0(0.0)$ \\
\hline Asthma & $4(6.7)$ & $0(0.0)$ \\
\hline COPD & $1(1.7)$ & $1(11.1)$ \\
\hline Obstructive sleep apnea & $2(3.3)$ & $0(0.0)$ \\
\hline HIV & $1(1.7)$ & $0(0.0)$ \\
\hline Transplant & $1(1.7)$ & $0(0.0)$ \\
\hline \multicolumn{3}{|l|}{ Concomitant therapies } \\
\hline Hydroxychloroquine & $52(86.7)$ & $8(88.9)$ \\
\hline Corticosteroids & $32(53.3)$ & $5(55.6)$ \\
\hline Inhaled nitric oxide & $5(8.3)$ & $1(11.1)$ \\
\hline Intravenous immunoglobulin (IVIG) & $4(6.6)$ & $0(0.0)$ \\
\hline Tacrolimus & $2(3.3)$ & $1(11.1)$ \\
\hline Convalescent plasma & $2(3.3)$ & $0(0.0)$ \\
\hline Plasmapheresis & $1(1.7)$ & $0(0.0)$ \\
\hline Time from symptom onset to hospital admission, median (range), days & $6(1-14)$ & $7(1-14)$ \\
\hline Time from hospital admission to receiving tocilizumab, median (range), days & $2(0-12)$ & $1(0-4)$ \\
\hline Time from symptom onset to receiving tocilizumab, median (range), days & $8(1-21)$ & $8(1-15)$ \\
\hline
\end{tabular}

Note: abnormal medians highlighted in bold

a Luo H, et al. Clin Lab 2019;65(3). 
Table 2 Clinical presentation on day of tocilizumab administration

\begin{tabular}{|c|c|c|c|}
\hline \multirow{2}{*}{$\frac{\text { Disease severity }}{\text { WHO Ordinal Scale }}$} & \multicolumn{3}{|l|}{$n(\%)$} \\
\hline & & & \\
\hline 8 (deceased) & \multicolumn{2}{|l|}{$0(0.0)$} & \\
\hline 7 (invasive mechanical ventilation + organ support) & \multicolumn{2}{|l|}{$17(28.3)$} & \\
\hline 6 (invasive mechanical ventilation) & \multicolumn{2}{|l|}{$9(15.0)$} & \\
\hline 5 (non-invasive ventilation or high-flow oxygen) & \multicolumn{2}{|l|}{$9(15.0)$} & \\
\hline 4 (oxygen by mask or nasal prongs) & \multicolumn{2}{|l|}{$24(40.0)$} & \\
\hline 3 (hospitalized without oxygen therapy) & \multicolumn{2}{|l|}{$1(1.7)$} & \\
\hline 1-2 (not hospitalized) & \multicolumn{2}{|l|}{$0(0.0)$} & \\
\hline Temperature $\geq 38^{\circ} \mathrm{C}$ & \multicolumn{2}{|l|}{$28(46.7)$} & \\
\hline Heart rate $\geq 100$ beats/min & \multicolumn{2}{|l|}{$34(56.7)$} & \\
\hline Respiratory rate $\geq 30$ breaths/min & \multicolumn{2}{|l|}{$36(60.0)$} & \\
\hline Abnormal chest imaging & \multicolumn{2}{|l|}{$59(98.3)$} & \\
\hline Vasopressor use & \multicolumn{2}{|l|}{$18(30.0)$} & \\
\hline Renal replacement therapy & \multicolumn{2}{|l|}{$4(6.7)$} & \\
\hline Use of paralytics & \multicolumn{2}{|l|}{$9(15.0)$} & \\
\hline Proned & \multicolumn{2}{|l|}{$5(8.3)$} & \\
\hline Room air & \multicolumn{2}{|l|}{$1(1.7)$} & \\
\hline Nasal cannula & \multicolumn{2}{|l|}{$18(30.0)$} & \\
\hline Venti-mask & \multicolumn{2}{|l|}{$3(5.0)$} & \\
\hline Nonrebreather & \multicolumn{2}{|l|}{$7(11.7)$} & \\
\hline High-flow nasal cannula & \multicolumn{2}{|l|}{$6(10.0)$} & \\
\hline Non-Invasive Positive Pressure Ventilation & \multicolumn{2}{|l|}{$2(3.3)$} & \\
\hline Invasive mechanical ventilation & \multicolumn{2}{|l|}{$23(38.3)$} & \\
\hline \multicolumn{4}{|l|}{ ARDS } \\
\hline Mild $\left(201<\mathrm{PaO}_{2} / \mathrm{FiO}_{2} \leq 300\right)$ & $13(21.7)$ & & \\
\hline Moderate $\left(101<\mathrm{PaO}_{2} / \mathrm{FiO}_{2} \leq 200\right)$ & $21(35.0)$ & & \\
\hline Severe $\left(\mathrm{PaO}_{2} / \mathrm{FiO}_{2} \leq 100\right)$ & $16(26.7)$ & & \\
\hline $\mathrm{PaO}_{2} / \mathrm{FiO}_{2}$, median (range) & $166(33-523)$ & & \\
\hline SOFA score, median (range) & $3(0-11)$ & & \\
\hline ICU care & $45(75.0)$ & & \\
\hline Laboratory parameters & Median (range) & Reference values & Number of patients with available data \\
\hline White blood cell count, $\times 10^{9} / \mathrm{L}$ & $9(2.7-29.6)$ & $4.0-10.5$ & 51 \\
\hline Absolute neutrophil count, $\times 10^{9} / \mathrm{L}$ & $6.85(1.8-26.8)$ & $2.0-6.0$ & 49 \\
\hline Absolute lymphocyte count, $\times 10^{9} / \mathrm{L}$ & $0.8(0.2-2.6)$ & $1.1-2.7$ & 48 \\
\hline Neutrophil-to-lymphocyte ratio (NLR) & $7.56(2.25-62)$ & $0.88-4^{\mathrm{a}}$ & 48 \\
\hline Hemoglobin, g/dL & $12.7(9-15.9)$ & $11.1-14.6$ & 51 \\
\hline RDW-CV, \% & $14(11.6-18.3)$ & $11-15$ & 51 \\
\hline Platelets, $\times 10^{9} / \mathrm{L}$ & $240(101-513)$ & $140-400$ & 49 \\
\hline Sodium, $\mathrm{mmol} / \mathrm{L}$ & $135(123-148)$ & $135-145$ & 53 \\
\hline $\mathrm{CO}_{2}, \mathrm{mmol} / \mathrm{L}$ & $24(11-36)$ & $22-30$ & 53 \\
\hline AST, U/L & $70.5(25-711)$ & $15-46$ & 46 \\
\hline $\mathrm{ALT}, \mathrm{U} / \mathrm{L}$ & $51.5(6-242)$ & $9-52$ & 46 \\
\hline Total bilirubin & $0.65(0.2-2.4)$ & $0.2-1.3$ & 48 \\
\hline Creatinine, mg/dL & $0.88(0.4-4.58)$ & $0.66-1.25$ & 53 \\
\hline
\end{tabular}


Table 2 Clinical presentation on day of tocilizumab administration (Continued)

\begin{tabular}{|c|c|c|c|}
\hline Disease severity & $n(\%)$ & & \\
\hline Interleukin-6, pg/mL & $133.9(8.73-2160.69)$ & none & 26 \\
\hline C-reactive protein, $\mathrm{mg} / \mathrm{dL}$ & $24.2(3.2-45)$ & $0.0-0.9$ & 49 \\
\hline Erythrocyte sedimentation rate, $\mathrm{mm} / \mathrm{hr}$ & $50(18-102)$ & $0-10$ & 24 \\
\hline Lactate dehydrogenase, U/L & 1333 (477-5089) & $313-618$ & 47 \\
\hline Ferritin, ng/mL & $1412.5(45-29,304)$ & $30-400$ & 46 \\
\hline Procalcitonin, ng/mL & $0.40(0.027-16.34)$ & $0-0.08$ & 33 \\
\hline D-dimer, $\mathrm{mcg} / \mathrm{mL}$ & $1.3(0.4->20)$ & $0-0.49$ & 33 \\
\hline Troponin, ng/mL & $0.104(<0.012-7.21)$ & $0-0.034$ & 15 \\
\hline
\end{tabular}

received hydroxychloroquine $(86.7 \%)$. Of the 32 patients that received steroids, $12.5 \%$ received $<6 \mathrm{mg} /$ day of dexamethasone equivalents, $15.6 \%$ received $6-20 \mathrm{mg} /$ day of dexamethasone equivalents, and $71.9 \%$ received $>20 \mathrm{mg} /$ day of dexamethasone equivalents. The median weight for our cohort was $91.5 \mathrm{~kg}$ (range 59182) and the average dose of tocilizumab administered was $4.75 \mathrm{mg} / \mathrm{kg}$. Forty-seven patients received a flat dose of $400 \mathrm{mg}$ and the remaining received 600 mg. Only 3 patients received a second dose of tocilizumab.
The clinical presentation of patients on the day of tocilizumab administration are described in Table 2. For disease severity, most patients scored a $4(40.0 \%)$ or 7 (28.3\%) based on the WHO COVID-19 ordinal scale. Most patients received oxygen supplementation via nasal cannula $(30.0 \%)$ or invasive mechanical ventilation (38.3\%). The median $\mathrm{PaO}_{2} / \mathrm{FiO}_{2}$ was 166 (range 33-523) and 50 patients $(83.3 \%)$ had ARDS. For abnormal laboratory values, we observed neutrophilia, lymphopenia, elevated neutrophil-to-lymphocyte ratio, elevated aspartate aminotransferase (AST), along with increased levels of

Table 3 Outcomes within 30 days of receiving tocilizumab

\begin{tabular}{|c|c|c|c|c|}
\hline$n(\%)$ & All & Received steroids & No steroids & $p$-value \\
\hline Clinical improvement & $36 / 60(60.0)$ & 13/36 (36.1\%) & 23/36 (63.9\%) & 0.0015 \\
\hline WHO ordinal scale on day of tocilizumab administration, median (range) & $4(3-7)$ & $4(4-7)$ & $4(3-7)$ & 0.47 \\
\hline WHO ordinal scale on day 30 , median (range) & $1(1-4)$ & $1(1-4)$ & $1(1-4)$ & - \\
\hline Mortality & $9 / 60(15.0)$ & $5 / 9(55.6 \%)$ & $4 / 9(44.4 \%)$ & 1.00 \\
\hline Time to death from receiving tocilizumab, median days (range) & $6(1-14)$ & & & \\
\hline Discharged alive & $33 / 60(55.0)$ & $15 / 33(45.5 \%)$ & 18/33 (54.5\%) & 0.27 \\
\hline Hospital length of stay, median days (range) & $15(0-32)$ & & & \\
\hline Required ICU care & $52 / 60(86.7)$ & $31 / 52(59.6 \%)$ & $21 / 52(40.4 \%)$ & 0.02 \\
\hline Remained admitted to ICU at day 30 & $13 / 52(25.0)$ & & & \\
\hline Step down to floor at day 30 & $5 / 52(9.6)$ & & & \\
\hline Discharged from hospital alive by day 30 & 25/52 (48.1) & & & \\
\hline Died by day 30 & $9 / 52(17.3)$ & & & \\
\hline Required invasive mechanical ventilation & $29 / 60(48.3)$ & $19 / 29(65.5 \%)$ & $10 / 29(34.5 \%)$ & 0.12 \\
\hline Successful extubation & $13 / 29(44.8)$ & $7 / 13(53.8 \%)$ & $6 / 13(46.2 \%)$ & 0.27 \\
\hline Duration of mechanical ventilation, median days (range) & $15(6-35)$ & & & \\
\hline Infectious complications & $16 / 60(26.7)$ & $10 / 16(62.5 \%)$ & $6 / 16(37.5 \%)$ & 0.57 \\
\hline Time to first infection, median days (range) & $10.5(2-28)$ & & & \\
\hline Cultures drawn while in ICU, $n(\%)$ & $26 / 29(89.7)$ & & & \\
\hline Cultures drawn while intubated, $n(\%)$ & $25 / 29(86.2)$ & & & \\
\hline \multicolumn{5}{|l|}{ Type of infection, $n(\%)$} \\
\hline Respiratory & $14 / 29(48.3)$ & & & \\
\hline Bloodstream & $14 / 29(48.3)$ & & & \\
\hline Urinary & $1 / 29(3.4)$ & & & \\
\hline
\end{tabular}


interleukin-6 (IL-6), C-reactive protein (CRP), erythrocyte sedimentation rate (ESR), lactate dehydrogenase (LDH), ferritin, procalcitonin, D-dimer, and troponin.

Outcomes for patients within 30 days from receiving tocilizumab are summarized in Table 3 . A total of 36 patients $(60.0 \%)$ achieved clinical improvement, 9 patients (15.0\%) died, 33 patients $(55.0 \%)$ were discharged from the hospital alive, and 18 patients (30.0\%) remained hospitalized. Of those who clinically improved, 13 patients
(36.1\%) received concomitant steroids. A total of 52 patients $(86.7 \%)$ resided in the ICU and $29(48.3 \%)$ patients required invasive mechanical ventilation. Thirteen patients (44.8\%) were successfully extubated within 30 days of tocilizumab administration. We identified 29 cultures in 16 patients $(26.7 \%)$ who developed infectious complications post-tocilizumab, with $10(62.5 \%)$ of these patients having received steroids. The median time to first infection was 10.5 days (range $2-28$ ). The most common

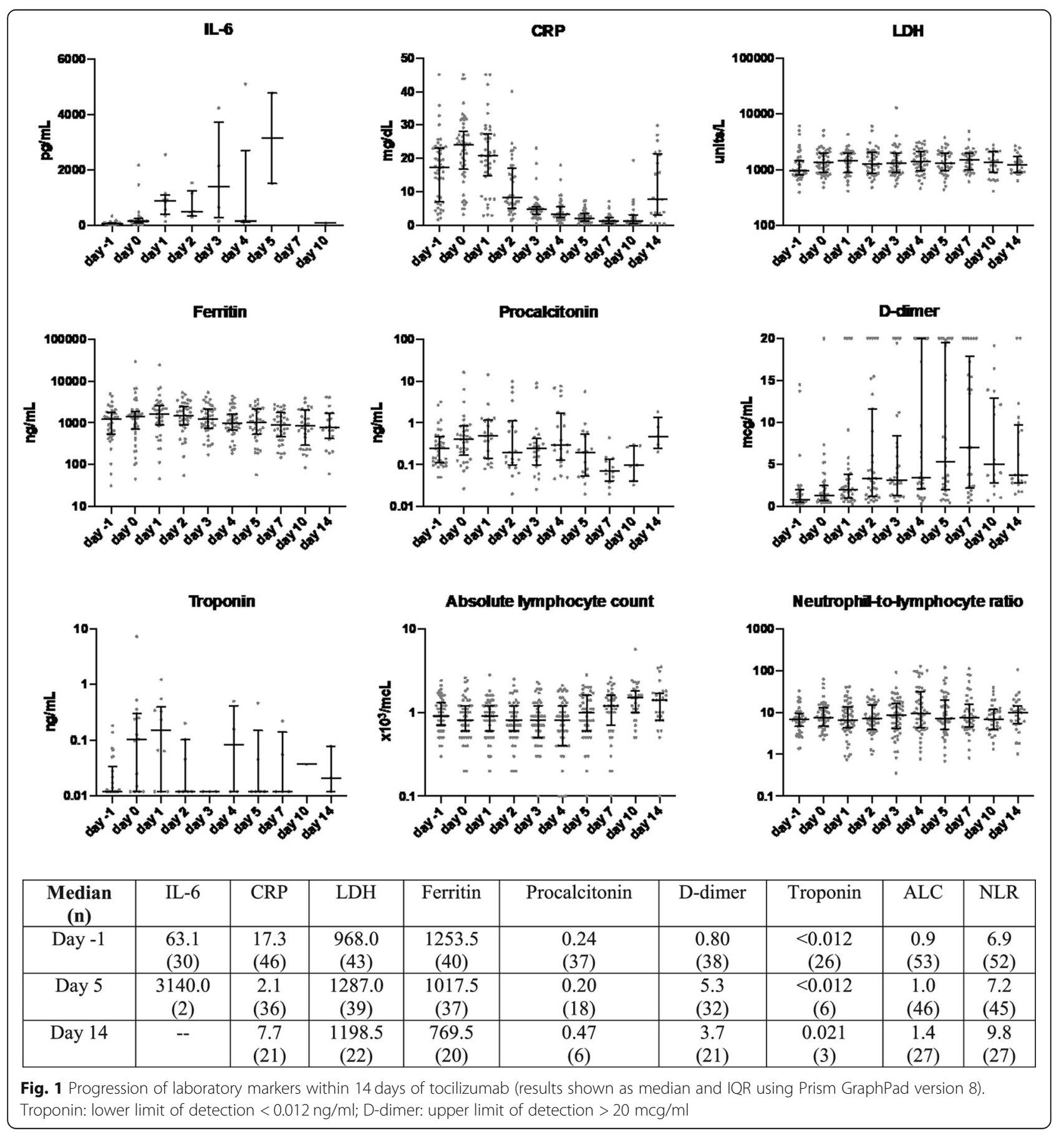


types of infection were respiratory (48.3\%) and bloodstream (48.3\%) (see Additional file 1: Appendix 3 supplemental material). We describe additional clinical measures pertaining to organ complications, modes of ventilation, and SOFA scores in Additional file 1: Appendix 2 supplemental material.

The progression of select laboratory and respiratory parameters within 14 days of tocilizumab are displayed in Fig. 1 and Fig. 2. We observed an initial reduction in CRP; however levels began to rise again after day 10. The opposite effect was seen with D-dimer. We saw an increase in IL-6 and improvements in both lymphopenia and oxygenation as measured by $\mathrm{PaO}_{2} / \mathrm{FiO}_{2}$. No clear trends were seen for lactate dehydrogenase, procalcitonin, troponin, or neutrophil-to-lymphocyte ratio (NLR).

\section{Discussion}

During the rapidly spreading pandemic, providers were faced with the challenge of recommending investigational agents for the treatment of COVID-19. Since

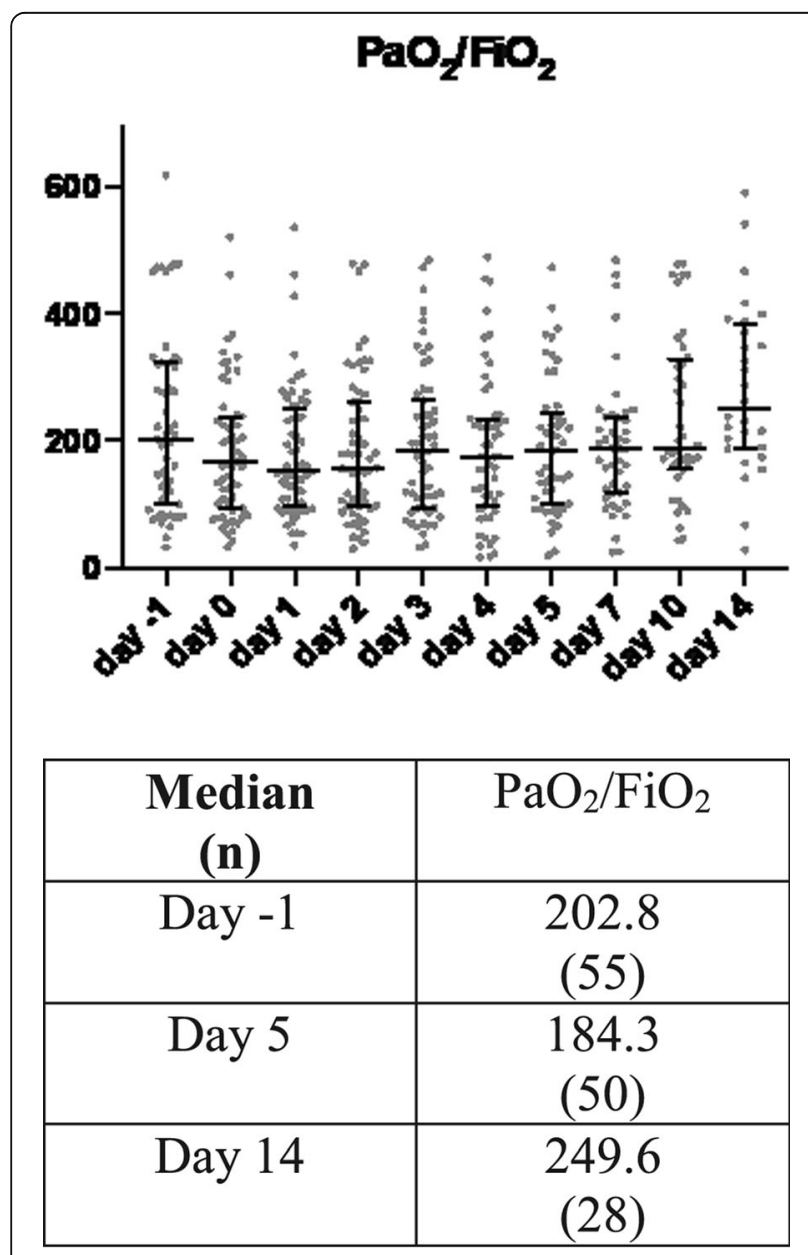

Fig. 2 Progression of oxygenation within 14 days of tocilizumab (results shown as median and IQR using Prism GraphPad version 8) elevated IL-6 levels have been associated with ICU admission, ARDS, and death, we chose to prescribe tocilizumab in patients with suspected CRS [6]. We aimed to provide early administration of tocilizumab in patients not yet on mechanical ventilation but with signs of worsening disease. Results from the EMPACTA trial demonstrated that patients who received tocilizumab were $44 \%$ less likely to progress to mechanical ventilation or death [26]. In our cohort, 9 out of the 31 patients who received tocilizumab early on later progressed to invasive mechanical ventilation. In the future, we hope to explore the effects of tocilizumab timing, as there may be a window of opportunity for preventing progressive respiratory failure.

Our patients presented with typical manifestations of COVID-19 and signs and symptoms of cytokine release syndrome. Similar to previous reports, patients with more severe disease demonstrated transaminitis, along with abnormal blood counts such as neutrophilia, lymphopenia, and elevated NLR ratio [4, 27]. After receipt of tocilizumab, CRP levels decreased but unlike other studies, this effect was not sustained [10-12]. CRP started to increase again after day 10 , which correlates with tocilizumab's elimination half-life of 11 to 13 days [28]. Compared to other studies where reductions in CRP remained until day 14, our patients received lower doses and the majority did not receive a second dose $[14,17]$. This suggests that tocilizumab's effect on CRP may be dose-dependent and that re-dosing after 10 days may be warranted. Previous pharmacokinetic data has also suggested that at least two doses of tocilizumab are needed to achieve adequate drug levels in plasma [7]. As expected, repeat IL-6 levels, although only available for one third of our patients, increased quickly after tocilizumab administration. This effect is known to occur after competitive binding of tocilizumab to the IL-6 receptor, resulting in the temporary accumulation of free IL- 6 in the serum [29]. We also observed an increase in D-dimer that peaked at day seven, and then decreased. Some have correlated D-dimer with the risk of developing pulmonary embolism in COVID but this was not investigated in our study. No clear trends were seen for LDH or procalcitonin, suggesting that these markers are non-specific to COVID-19.

There are mixed results on the effects of oxygenation after tocilizumab administration in COVID-19 patients. Studies have reported improvements in oxygenation while others did not $[11,13,30]$. We observed an overall increase in $\mathrm{PaO}_{2} / \mathrm{FiO}_{2}$ after tocilizumab, but it is unclear whether this was a drug effect or more so reflects the natural course of ARDS. One study found no association between tocilizumab and $\mathrm{FiO}_{2}$ reduction [17]. By day 30, extubation occurred in 13 out of 29 patients (44.8\%). Rates of extubation for COVID-19 have only been recorded in a small study where 2 out of 3 patients 
were successfully extubated after receiving tocilizumab [10].

By our study endpoint, 36 patients (60.0\%) demonstrated clinical improvement and 33 patients (55.0\%) were discharged alive. Our discharge rate was very similar to the $56 \%$ reported by Somers et al. [15]. We observed a 30day mortality rate of $15 \%$, which falls within the range (13-27\%) of previous studies [10, 12, 15, 16, 30, 31]. Many studies have already investigated the relationship of tocilizumab and mortality in COVID-19 patients, but with mixed findings. Salvarani et al. and Campochiaro et al. found no significant difference in mortality in patients receiving tocilizumab $[18,31]$. In contrast, several other studies have shown tocilizumab to be associated with a decreased risk of death, lower hospital-related mortality, as well as reduced risk of all-cause mortality [15-17, 19, 20]. However, it is important to note that many of these studies allowed for concominant steroid use, a known confounder towards better survival [32]. When comparing our patients who received steroids with tocilizumab to those who did not, the cohort who received steroids surprisingly did worse. More patients died, less demonstrated clinical improvement, and less were discharged from the hospital alive despite having similar baseline COVID-19 disease severity. We believe this could be explained by the use of higher steroid doses in our study; most patients received dosages greater than $6 \mathrm{mg}$ daily of dexamethasone equivalents and as a result, were more immunosuppressed than the RECOVERY population.

Another hypothesis for worse outcomes when combining steroid with tocilizumab is the higher incidence of infectious complications in the steroid group $(62.5 \%$ vs. $37.5 \%, p=0.57$ ), although this was not statistically significant. Tocilizumab is immunosuppressive and has been linked to secondary infections [33, 34]. In our study, we identified an overall infection rate of $26.7 \%$ within 30 days of receiving tocilizumab. Another study with a longer follow-up time of 8 weeks found a higher infection of incidence at 64.2\%; however, they used a broader definition for infections that included both highly suspected infections and confirmed infections [35]. Additional studies have reported infection rates possibly secondary to tocilizumab [15-17]. Somers et al. reported a two-fold higher incidence of infection (54\% vs. $26 \%, p<0.001)$ however more patients in the tocilizumab arm received steroids [15]. So far, the only study that excluded concomitant steroids found a lower incidence of infections with tocilizumab $(8.1 \%$ vs. $17.3 \%, p=$ 0.03) [21]. Therefore, it remains unclear whether tocilizumab, when used by itself, increases the risk of infection.

Our study had several limitations. First, it was a small retrospective study with no matched control group. Second, the flat doses of 400 and $600 \mathrm{mg}$ for tocilizumab could have resulted in lower than optimal doses if extrapolating from FDA-approved $(8 \mathrm{mg} / \mathrm{kg})$ doses for CAR T cell-induced CRS [7]. Third, many patients received concomitant therapies that could impact clinical outcomes. Fourth, many of our respiratory infections were diagnosed based on tracheal aspirates because bronchoscopies were infrequent at the time. Lastly, the study was descriptive and not aimed to investigate predisposing risk factors for infectious complications or to determine tocilizumab efficacy.

\section{Conclusion}

In this study, we demonstrated the effects of tocilizumab in 60 patients with COVID-19. We primarily used tocilizumab in patients presenting with signs of cytokine release syndrome and acute respiratory distress syndrome. Many patients achieved clinical improvement and were eventually discharged from the hospital. Our most interesting finding was the rebound effect seen with Creactive protein after day 10 , which suggests the need for higher or subsequent doses. Similar to prior studies, infectious complications after tocilizumab were not uncommon. Our results highlight the need for more robust studies investigating the safety, efficacy, and optimal timing of tocilizumab in COVID-19 patients.

\section{Supplementary Information}

The online version contains supplementary material available at https://doi. org/10.1186/s12879-020-05701-4.

Additional file 1: Appendix 1. Patients meeting institution-specific tocilizumab criteria. Appendix 2. Clinical measures within 14 days of receiving tocilizumab. Appendix 3. Infectious complications within 30 days of receiving tocilizumab

\section{Abbreviations}

COVID-19: Coronavirus Disease 2019: SARS-CoV-2: Severe acute respiratory syndrome coronavirus 2; CRS: Cytokine release syndrome; IL-6: Interleukin-6; ARDS: Acute respiratory distress syndrome; CAR: Chimeric antigen receptor; IV: Intravenous; SpO2: Saturation of peripheral oxygen; PCR: Polymerase chain reaction; WHO: World Health Organization; ICU: Intensive care unit; $\mathrm{PaO}_{2}$ / $\mathrm{FiO}_{2}$ : Partial pressure of oxygen/fraction of inspired oxygen; ABG: Arterial blood gas; AST: Aspartate aminotransferase; CRP: C-reactive protein; ESR: Erythrocyte sedimentation rate; LDH: Lactate dehydrogenase; NLR: Neutrophil-to-lymphocyte ratio

\section{Acknowledgements \\ We would like to thank all the health care providers who have risked their lives caring for COVID-19 patients.}

\footnotetext{
Authors' contributions

CAV: Conceptualization, Methodology, Formal analysis, Data curation, Writing - Original Draft, Writing- Review \& Editing, Visualization. KJD:

Conceptualization, Methodology, Data curation, Writing - Original Draft, Writing- Review \& Editing. ADV: Conceptualization, Methodology, Data curation, Writing - Original Draft, Writing- Review \& Editing. MM:

Conceptualization, Methodology, Data curation, Writing - Original Draft, Writing- Review \& Editing. GH: Conceptualization, Methodology, Formal analysis, Writing- Review \& Editing. YN: Conceptualization, Methodology, Writing- Review \& Editing. JGZ: Conceptualization, Methodology, Formal analysis, Writing- Review \& Editing. VS: Data curation, Writing- Review \&
} 
Editing. RB: Data curation, Writing- Review \& Editing. SRM: Conceptualization, Investigation, Writing- Review \& Editing. DD: Investigation. AF: Investigation. LC: Investigation. JK: Investigation. AL: Investigation. AHR: Investigation. YR: Investigation. GMM: Investigation. SD: Writing- Review \& Editing. DJD: Writing- Review \& Editing. LMA: Conceptualization, Methodology, WritingReview \& Editing, Supervision. The authors read and approved the final manuscript.

\section{Funding}

This research did not receive any specific grant from funding agencies in the public, commercial, or not-for-profit sectors.

\section{Availability of data and materials}

The datasets used in this study are available from the corresponding author on reasonable request.

\section{Ethics approval and consent to participate}

This study was approved by the University of Miami Institutional Review Board and Jackson Health System Clinical Research Review Committee (CRRC) and a waiver of informed consent was granted. Data collected from the study participants was kept anonymous and treated as confidential at all times.

\section{Consent for publication}

Not applicable.

\section{Competing interests}

The authors declare that they have no competing interests.

\section{Author details}

'Department of Pharmacy, Jackson Health System, Miami, FL, USA. ${ }^{2}$ Jackson Memorial Hospital, Pharmacy Services, B069, 1611 NW 12th Ave, Miami, FL 33136, USA. ${ }^{3}$ Division of Pulmonary Critical Care, Department of Medicine, University of Miami Miller School of Medicine, Miami, FL, USA. ${ }^{4}$ Division of Infectious Diseases, Department of Medicine, University of Miami Miller School of Medicine, Miami, FL, USA. ${ }^{5}$ University of Miami Miller School of Medicine, Miami, FL, USA. 'Department of Pediatrics, Jackson Health System/ Holtz Children's Hospital, Miami, FL, USA.

\section{Received: 26 July 2020 Accepted: 9 December 2020}

\section{Published online: 22 December 2020}

\section{References}

1. Chen N, Zhou M, Dong X, Qu J, Gong F, Han Y, Qiu Y, Wang J, Liu Y, Wei Y, Xia J, YU T, Zhang X, Zhang L. Epidemiological and clinical characteristics of 99 cases of 2019 novel coronavirus pneumonia in Wuhan, China: a descriptive study. Lancet. 2020;395(10223):507-13.

2. Ackermann M, Verleden SE, Kuehnel M, Haverich A, Welte T, Laenger F, Vanstapel A, Werlein C, Stark H, Tzankov A, Li WW, Li WW, Mentzer SJ, Jonigk D. Pulmonary vascular endothelialitis, thrombosis, and angiogenesis in Covid-19. N Engl J Med. 2020;383:120-8. https://doi.org/10.1056/ NEJMoa2015432.

3. Brune K, Frank J, Schwingshackl A, Finigan J, Sidhaye VK. Pulmonary epithelial barrier function: some new players and mechanisms. Am J Physiol Lung Cell Mol Physiol. 2015;308(8):L731-45.

4. Siddiqi HK, Mehra MR. COVID-19 illness in native and immunosuppressed states: a clinical-therapeutic staging proposal. J Heart Lung Transplant. 2020; 39(5):405-7.

5. Zhang C, Wu Z, Li J, Zhao H, Wang G. Cytokine release syndrome in severe COVID-19: interleukin-6 receptor antagonist tocilizumab may be the key to reduce the mortality. Int J Antimicrob Agents. 2020;55(5):105954.

6. Coomes EA and Haghbayan H. Interleukin-6 in COVID-19: A systematic review and meta-analysis. medRxiv 2020. https://doi.org/10.1101/2020.03.30. 20048058. (pre-print).

7. Le RQ, Li L, Yuan W, Shord SS, Nie L, Habtemariam BA, Przepiorka D, Farrell AT, Pazdur R. FDA approval summary: tocilizumab for treatment of chimeric antigen receptor $\mathrm{t}$ cell-induced severe or life-threatening cytokine release syndrome. Oncologist. 2018;23(8):943-7.

8. Giamarellos-Bourboulis EJ, Netea MG, Rovina N, Akinosoglou K, Antoniadou A, Antonakos N, Damoraki G, Gkavogianni T, Adami M, Katsaounou P, Ntaganou M, Kyriakopoulou M, Dimopoulos G, Koutsodimitropoulos I,
Velissaris D, Koufargyris P, Karageorgos A, Katrini K, Lekakis V, Lupse M, Kotsaki A, Renieris G, Theodoulou D, Panou V, Koukaki E, Koulouris N, Gogos C, Koutsoukou A. Complex Immune Dysregulation in COVID-19 Patients with Severe Respiratory Failure. Cell Host Microbe 2020; 27(6):992-1000.e3.

9. Alzghari SK, Acuña VS. Supportive treatment with tocilizumab for COVID-19: a systematic review. J Clin Virol. 2020;127:104380.

10. Luo P, Liu Y, Qiu L, Lui X, Liu D, Li J. Tocilizumab treatment in COVID-19: a single center experience. J Med Virol. 2020;92(7):814-8.

11. Xu X, Han M, Li T, Sun W, Wang D, Fu B, Zhou Y, Zheng X, Yang Y, Li X, Zhang X, Pan A, Wei H. Effective treatment of severe COVID-19 patients with Tocilizumab. Proc Natl Acad Sci U S A. 2020;117(20):10970-5.

12. Sciascia $S$, Aprà F, Baffa $A$, Baldovino $S$, Boaro D, Boero R, Bonora $S$, Calcagno A, Cecchi I, Cinnirella G, Converso M, Cozzi M, Crosasso P, De laco F, Perri GD, Eandi M, Fenoglio R, Giusti M, Imperiale D, Imperiale G, Livigni $S$, Manno E, Massara C, Milone V, Natale G, Navarra M, Oddone V, Osella S, Piccioni P, Radin M, Roccatello D, Rossi D. Pilot prospective open, single arm multicentre study on off-label use of tocilizumab in patients with severe COVID-19. Clin Exp Rheumatol. 2020;38(3):529-32.

13. Capra R, De Rossi N, Mattioli F, Romanelli G, Scarpazza C, Sormani MP, Cossi S. Impact of low dose tocilizumab on mortality rate in patients with COVID19 related pneumonia. Eur J Intern Med. 2020;76:31-5.

14. Hermine $O$, Mariette $X$, Tharaux P, Resche-Rigon M, Porcher R, Ravaud P. CORIMUNO-19 Collaborative Group. JAMA Intern Med. 2020. https://doi.org/ 10.1001/jamainternmed.2020.6820.

15. Somers EC, Eschenauer GA, Troost JP, Golob JL, Gandhi TN, Wang L, Zhou N, Petty LA, Baang JH, Dollman NO, Frame D, Gregg KS, Kaul DR, Nagel J, Patel TS, Zhou S, Lauring AS, Hanauer DA, Martin E, Sharma P, Fung CM, Pogue JM. Tocilizumab for treatment of mechanically ventilated patients with COVID-19. medRxiv 2020. https:/doi.org/10.1101/2020.05.29.20117358. (preprint).

16. Guaraldi G, Meschiari M, Cozzi-Lepri A, Milic J, Tonelli R, Menozzi M, Franceschini E, Cuomo G, Orlando G, Borghi V, Santoro A, Di Gaetano M, Puzzolante C, Carli F, Bedini A, Corradi L, Fantini R, Castaniere I, Tabbì L, Girardis M, Tedeschi S, Gianella M, Bartoletti M, Pascale R, Dolci G, Brugiono L, Pietrangelo A, Cossarizza A, Pea F, Clini E, Salvarani C, Massari M, Viale PL, Mussini C. Tocilizumab in patients with severe COVID-10: a retrospective cohort study. Lancet Rhematol. 2020;2(8):e474-84. https://doi.org/10.1016/ S2665-9913(20)30173-9.

17. Biran N, Ip A, Ahn J, Go RC, Wang S, Mathura S, Sinclaire BA, Bednarz U, Marafelias M, Hansen E, Siegel DS, Goy AH, Pecora AL, Sawczuk IS, Koniaris LS, Simwenyi M, Varga DW, Tank LK, Stein AA, Allusson V, Lin GS, Oser WF, Tuma RA, Reichman J, Brusco L Jr, Carpenter KL, Costanzo EJ, Vivona V, Goldberg SL. Tocilizumab among patients with COVID-19 in the intensive care unit: a multicentre observational study. Lancet Rhematol. 2020;2(10): e603-12. https://doi.org/10.1016/S2665-9913(20)30277-0.

18. Salvarani C, Dolci G, Massari M, Merlo DF, Cavuto S, Savoldi L, Bruzzi P, Boni F, Braglia L, Turrà C, Ballerini PF, Sciascia R, Zammarchi L, Para O, Scotton PG, Inojosa WO, Ravagnani V, Salerno ND, Sainaghi PP, Brignone A, Codeluppi M, Teopompi E, Milesi M, Bertomoro P, Claudio N, Salio M, Falcone M, Cenderello G, Donghi L, Del Bono V, Colombelli PL, Angheben A, Passaro A, Secondo G, Pascale R, Piazza I, Facciolongo N, Costantini M, RCT-TCZ-COVID-19 Study Group. Effect of tocilizumab vs standard care on clinical worsening in patients hospitalized with COVID-19 pneumonia. JAMA Intern Med. 2020. https://doi.org/10.1001/jamainternmed.2020.6615.

19. Martínez-Sanz J, Muriel A, Ron R, Herrera S, Pérez-Molina JA, Moreno S, Serrano-Villar $\mathrm{S}$. Effects of tocilizumab on mortality in hospitalized patients with COVID-19: a multicenter cohort study. Clin Microbiol Infect. 2020. https://doi.org/10.1016/j.cmi.2020.09.021.

20. Gupta S, Wang W, Hayek SS, Chan L, Mathews KS, Melamed ML, Brenner SK, Leonberg-Yoo A, Schenck EJ, Radbel J, Reiser J, Bansal A, Srivastava A, Zhou Y, Finkel D, Green A, Mallappallil M, Faugno AJ, Zhang J, Velez JC, Shaefi S, Parikh CR, Charytan DM, Athavale AM, Friedman AN, Redfern RE, Short SAP, Correa S, Pokharel KK, Admon AJ, Donnelly JP, Gershengorn HB, Douin DJ, Semler MW, Hernán MA, Leaf DE. STOP-COVID investigators. JAMA Intern Med. 2020. https://doi.org/10.1001/jamainternmed.2020.6252.

21. Stone JH, Frigault MJ, Serling-Boyd NJ, Fernandes AD, Harvey L, Foulkes AS, Horick NK, Healy BC, Shah R, Bensaci AM, Wooley AE, Nikiforow S, Lin N, Sagar M, Schrager H, Huckins DS, Axelrod M, Pincus MD, Fleisher J, Sacks CA, Dougan M, North CM, Halvorsen Y, Thurber TK, Dagher Z, Scherer A, Wallwork RS, Kim AY, Schoenfeld S, Sen P, Neilan TG, Perugino CA, Unizony SH, Collier DS, Matza MA, Yinh JM, Bowman KA, Meyerowitz E, Zafar A, Drobni ZD, Bolster MB, Kohler M, KM D'S, Dau J, Lockwood MM, Cubbison 
C, Weber BN, Mansour MK, BACC Bay Tocilizumab Trial Investigators. Efficacy of tocilizumab in patients hospitalized with Covid-19. N Engl J Med. 2020; 383:2333-44. https://doi.org/10.1056/NEJMoa2028836.

22. China's National Health Commission. Novel coronavirus treatment guidelines - 7th Edition. 2020.

23. World Health Organization. WHO R\&D Blueprint novel Coronavirus: COVID19 Therapeutic Trial Synopsis. 2020.

24. Rice TW, Wheeler AP, Bernard GR, Hayden DL, Schoenfeld DA, Ware LB. Comparison of the $\mathrm{SpO} / \mathrm{FIO} 2$ ratio and the $\mathrm{PaO} 2 / \mathrm{FlO} 2$ ratio in patients with acute lung injury or ARDS. Chest. 2007;132(2):410-7.

25. Definition Task Force ARDS, Ranieri VM, Rubenfeld GD, Thompson BT, Ferguson ND, Caldwell E, Fan E, Camporota L, Slutsky AS. Acute respiratory distress syndrome: the Berlin Definition. JAMA. 2012;307(23):2526-33.

26. ClinicalTrials.gov. A Study to Evaluate the Efficacy and Safety of Tocilizumab in Hospitalized Participants With COVID-19 Pneumonia (EMPACTA). Available from https://clinicaltrials.gov/ct2/show/NCT04372186. Accessed $27 \mathrm{Sep}$ 2020.

27. Lippi G, Plebani M. Laboratory abnormality in patients with COVID-2019 infection. Clin Chem Lab Med. 2020;58(7):1131-4.

28. Actemra (tocilizumab) [prescribing information]. South San Francisco: Genentech Inc; 2020.

29. Nishimoto N, Terao K, Mima T, Nakahara H, Takagi N, Kakehi T. Mechanisms and pathologic significance in increase in serum interleukin-6 (IL-6) and soluble IL-6 receptor after administration of an anti-IL-6 receptor antibody, tocilizumab, in patients with rheumatoid arthritis and Castleman disease. Blood. 2008:112(10):3959-64.

30. Rimland CA, Morgan CE, Bell GJ, Kim MK, Hedrick T, Marx A, Bramson B, Swygard H, Napravnik S, Schmitz JL, Carson SS, Fischer WA, Eron JJ, Gay CL, Parr JB. Clinical characteristics and early outcomes in patients with COVID19 treated with tocilizumab at a United States academic center. medRxiv 2020. https://doi.org/10.1101/2020.05.13.20100404. (preprint).

31. Campochiaro C, Della-Torre E, Cavalli G, De Luca G, Ripa M, Boffini N, Tomelleri A, Baldissera E, Rovere-Querini P, Ruggeri A, Monti G, De Cobelli F, Zangrillo A, Tresoldi M, Castagna A, Dagna L, TOCI-RAF Study Group. Efficacy and safety of tocilizumab in severe in COVID-19 patients: a singleCentre retrospective cohort study. Eur J Intern Med. 2020;76:43-9.

32. Horby P, Lim WS, Emberson JR, Mafham M, Bell JL, Linsell L, Staplin N, Brightling C, Ustianowski A, Elmahi E, Prudon B, Green C, Felton T, Chadwick D, Rege K, Fegan C, Chappell LC, Faust SN, Jaki T, Jeffery K, Montgomery A, Rowan K, Juszczak E, Baillie JK, Haynes R, Landray MJ. RECOVERY Collaborative Group. N Engl J Med. 2020. https://doi.org/10.1056/ NEJMoa2021436.

33. Navarro G, Taroumian $S$, Barroso N, Duan L, Furst D. Tocilizumab in rheumatoid arthritis: a meta-analysis of efficacy and selected clinical outcomes. Semin Arthritis Rheum. 2014;43(4):458-69.

34. Hill JA, Li D, Hay KA, Green ML, Cherian S, Chen X, Riddell SR, Maloney DG, Boeckh M, Turtle CJ. Infectious complications of CD19-targeted chimeric antigen receptor-modified T-cell immunotherapy. Blood. 2018:131(1):121-30

35. Kimmig LM, Wu D, Gold M, Pettit NN, Pitrak D, Mueller J, Husain AN, Mutlu EA, Mutlu GM. IL6 inhibition in critically ill COVID-19 patients is associated with increased secondary infections. medRxiv 2020. https://doi.org/10.1101/ 2020.05.15.20103531. (preprint).

\section{Publisher's Note}

Springer Nature remains neutral with regard to jurisdictional claims in published maps and institutional affiliations.

Ready to submit your research? Choose BMC and benefit from:
- fast, convenient online submission
- thorough peer review by experienced researchers in your field
- rapid publication on acceptance
- support for research data, including large and complex data types
- gold Open Access which fosters wider collaboration and increased citations
- maximum visibility for your research: over 100M website views per year
At BMC, research is always in progress.
Learn more biomedcentral.com/submissions

